\title{
Protection of Indigenous Legal Rights towards Traditional Knowledge Used by Foreign Parties According to International Law Perspective
}

\author{
Billy Panjaitan $^{1 *}$, Kholis Roisah $^{2 *}$ \\ \{bil@gmail.com ${ }^{1}$, kholisroisah.fh.undip@gmail.com ${ }^{2 *}$ \}
}

Fakultas Hukum, Universitas Diponegoro, Jl. Prof. H. Soedarto, S.H., Semarang, Indonesia $50275^{1,2}$

\begin{abstract}
Traditional Knowledge (TK) is a knowledge that indigenous people have over the results of interactions with their territories. Nowadays, TK is considered as a commodity for foreign parties, such as companies, for product development that can reduce research operations and costs. Oftentimes, the rights of indigenous peoples to TK are ignored for the commercial interests of the company. Internationally, regulations to accommodate TK has not yet been established, but the rights of indigenous peoples have been regulated in several legal instruments. This research showed that the rights of indigenous peoples to TK has been accommodated in international legal instruments such as the International Covenant on Civil and Political Rights, United Nations Declaration on the Rights of Indigenous Peoples, Convention on Biological Diversity, and Nagoya Protocol. Base on the provisions of the CBD and the Nagoya Protocol, that all parties, foreign parties, who make use of traditional knowledge held by indigenous peoples must take the steps of Prior-informed consent, establish a Mutual Agreement Term (MTA), and establish access and benefit sharing (ABS) so that the benefits of using traditional knowledge can be returned to indigenous peoples for social, economic, cultural and general welfare.
\end{abstract}

Keywords: Rights of Indigenous Peoples, Traditional Knowledge, Utilization, International Law

\section{Introduction}

Indigenous peoples live in areas not far from their daily needs. Indigenous peoples in integration with their territories create close relations with their environment. This close relationship gives birth to the results of empirical experience from local communities in adapting to the environment and natural resource management. The results of this relationship can be called traditional knowledge.[1] This traditional knowledge has various benefits, one of which is for the treatment and cure of various diseases.[1]

This traditional knowledge information is very useful for the public.[2] The value of the use of traditional knowledge has become recognized by various parties, among others, scientists and policy makers, and is a growing subject of national and international law.[3] Because of the usefulness of this traditional knowledge information, traditional knowledge is often misused, for example using without permission by parties outside indigenous peoples, [4] such as foreign parties. This abuse is called biopiracy which means illegal commercial use of 
biological resources and/or related traditional knowledge, or patents of fake inventions based on that knowledge, without compensation. [1]

Some biopiracy cases conducted by foreign parties are recorded in several countries, such as the Basmati Rice Case (India v. United States),[5] Shiseido Case (Indonesia v. Japan),[6] The case of Ayahuasca (Brazil v. United States),[7] and others. Some of these cases reflect abuse in the form of claims for inventions based on traditional knowledge with commercial intentions.

One of the causes of this biopiracy is the advancement of global technological knowledge. Based on research in 1985, the economic value of the sale of medicines that contain components of genetic resources or traditional knowledge, which are usually first used by indigenous peoples, is estimated at US \$ 43 billion.[8] According to Kate and Laird who conducted a study of the commercial use of biodiversity that intersected genetic resources and traditional knowledge in 1999, products derived from genetic resources were valued at between US $\$ 500$ billion to US $\$ 800$ billion.[9] This figure is based on statistics from the pharmaceutical industry sector, botanical medicines, agricultural products (including agricultural seeds), horticultural products, biotechnology, and personal care products and cosmetics.

Utilization of traditional knowledge is economically beneficial for the industry, but on the other hand, it is detrimental to the interests of local communities and host countries. [8] The rights of indigenous peoples are a matter that has been ruled out for the economic interests of industrial players,[11] as in the case above. Erstling argues that "... that communities should have the right to use of their own Traditional Knowledge pursuant to their own customs and policies."'[12] According to him, indigenous people must have the right to use their own traditional knowledge in accordance with their habits and policies, free from fraud or misuse by other parties.

Internationally, discussions regarding the protection of traditional knowledge have been discussed decades ago. The international community has difficulty meeting agreements for traditional knowledge due to its diverse and dynamic nature.[13] These issues are currently under discussion at the Intergovernmental Committee of the World Intellectual Property Organization (WIPO) which is considering agreements that protect traditional knowledge of indigenous peoples, traditional cultural expressions, and genetic resources.[2]

Moving on from these discussions then resulted in several important international agreements related to the legal protection of indigenous peoples' rights to traditional knowledge,[11] particularly on instruments that move from the realm of human rights law to international environmental law.

Various legal problems arise from this problem, starting from the regulation of the protection of the rights of indigenous peoples to traditional knowledge both on an international and national scale still has limitations in its regulation, as well as its implementation. Even when foreign parties make use of this knowledge. This study discusses the protection of the rights of indigenous peoples to traditional knowledge utilized by foreign parties from the perspective of International Law. 


\section{Method}

The method used in this research is normative judicial approach. often referred to as library law research. The research specifications used are descriptive analytical and qualitative data analysis. statistical procedures and other forms of calculation.

\section{Results and Discussion}

There are three main reasons why traditional knowledge needs to be protected.[9] First, to improve the lives of traditional knowledge holders. Traditional knowledge is very valuable for indigenous peoples who depend on traditional knowledge for their health, livelihood and general welfare.[14] Second, to protect traditional knowledge from misuse. Put simply, the misuse of traditional knowledge arises when in use, it does not ask permission in advance for commercial purposes. Third, economic benefits. Some traditional medicines are used as input in biomedical research, showing that these drugs can be a source of income not only as drugs but also as sources of chemicals that form the basis of pharmaceuticals. Indeed, indigenous peoples have been responsible for the discovery, development and preservation of extraordinary medicinal plants, herbal formulations that provide health, agricultural and forest products, handicrafts that are traded internationally and produce great economic value, but not for that community.[9]

Until now, international law has not yet regulated specific arrangements for traditional knowledge, but has accommodated regulations on the interests of indigenous peoples in general. The absence of an international agreement that explicitly regulates the protection of traditional knowledge does not mean that there is no protection at all. Attention to the legal protection of indigenous peoples' rights to traditional knowledge has led to the establishment of several international legal instruments that recognize and protect the rights of indigenous peoples to enjoy their cultural heritage, including traditional knowledge.[11] Indigenous peoples themselves have repeatedly claimed that they have a fundamental right to traditional knowledge because it is needed for the survival of their culture, and this principle is increasingly recognized in international law.[3] International law, at least, has governed this issue in three international legal regimes, namely as follows:

\subsection{Human Rights Legal Regime}

There are several provisions in these legal instruments, but the provisions are interconnected and mutually supportive of one another. Some of these instruments are Article 27 (1) and (2) Universal Declaration of Human Rights 1948 or Universal Declaration of Human Rights 1948 (UDHR), Article 15 paragraph (1) International Covenant on Economic, Social and Cultural Rights 1966 or International Covenant Economic, Social and Cultural Rights 1966 (ICESCR) and Article 27 International Covenant on Civil and Political Rights 1966 or International Covenant on Civil and Political Rights 1966 (ICCPR).

This declaration and the Covenant are the arrangements for each human being as an individual. The above legal instruments do not explicitly regulate that indigenous peoples are protected from traditional knowledge. Apparently, Article 27 (2) UDHR and 15 (1) (c) ICESCR indicate copyright in accommodation. This view is also reinforced through the UDHR and ICESCR travaux préparatoires, the rights listed are clearly bound to an individual 
author or inventor and cannot be held by a group.[15] Based on this, the UDHR and ICESCR protect the intellectual property rights law of individuals and do not protect the rights of indigenous peoples to traditional knowledge.

In addition, the provisions in Article 27 of the ICCPR are deemed relevant enough to protect the rights of indigenous peoples to traditional knowledge, this provision states that, in essence, people belonging to such minority groups may not be denied their rights in the community, together with other members of their groups, to enjoy their own culture.

Although indigenous peoples insist they do not consider themselves to be a minority, [16] the provisions of this article can be applied to them as indigenous peoples and are strengthened through The Human Rights Committee in General Comment No. 3 states that:

"... the Committee observes that culture manifests itself in many forms, including certain ways of life related to the use of land resources, especially in the case of indigenous peoples. That right can include traditional activities such as fishing or hunting and the right to live in reserves protected by law." [17]

Then the term 'culture' in Article 27 of the ICCPR is very broad in meaning, but according to the conceptual approach by Stavenhagen, 'culture' can be interpreted, one of which, namely:

"Culture as a way of life, the total amount of material and spiritual activities and products of certain social groups that distinguish it from other similar groups. Culture is also seen as a coherent independent system of values, and a symbol and set of practices that reproduce certain cultural groups from time to time and that provide individuals with the signs and meanings needed for social behavior and relationships in everyday life." [18]

Thus, the Human Rights Law regime with regard to the rights of indigenous peoples to traditional knowledge. At a glance, these instruments require parties outside indigenous peoples, such as foreigners, to respect the cultural life of indigenous peoples in using traditional knowledge. Although these instruments do not directly regulate indigenous peoples, these provisions can be a very basic consideration for the establishment of regulations for protecting indigenous peoples' rights to traditional knowledge in particular.

\subsection{Ad Hoc Regime on Indigenous Peoples}

Some of these legal instruments regulate indigenous peoples, namely International Labor Organization Convention No. 169 regarding Indigenous and Tribal Peoples in Independent Countries or the International Labor Organization Convention No. 169 Concerning Indigenous and Tribal Peoples in Independent Countries 1989 (ILO Convention No. 169) and the United Nations Declaration on the Rights of Indigenous Peoples, the United Nations Declaration on the Rights of Indigenous Peoples 2007 (UNDRIP).

Regarding traditional knowledge, ILO Convention No. 169 does not directly regulate traditional knowledge. According to Article 23 of ILO Convention No. 169 in essence outlines a number of provisions covering various traditional activities by indigenous peoples which are important factors in the preservation of their culture. Some provisions in Article 13 and 15 of ILO Convention No. 169 can also be considered,[15] however again, ILO Convention No. 169 recognize the rights of indigenous peoples, but do not explicitly regulate indigenous peoples' rights to traditional knowledge. 
In addition to ILO Convention No. 169, Article 31 of the UNDRIP which states that, "Indigenous people have the right to maintain, control, protect and develop their cultural heritage, traditional knowledge and traditional cultural expressions ... ." Indigenous peoples can establish various arrangements relating to the use, distribution and access to traditional knowledge. Foreign parties are required to request Prior Information Based Approval (PADIA) from indigenous peoples before acquiring and utilizing traditional knowledge.[19]

The provisions of the UNDRIP can certainly be a legal umbrella for indigenous peoples when their traditional knowledge is used unilaterally or without their permission by foreign parties, however, in terms of the shape of this instrument, it has weaknesses. The subject of the Declaration has not developed enough, or there is no consensus on the content of the principles (norms) or rules for them to be realized in the agreement.[20] In addition, the Declaration is actually a non-legally binding instrument (instrument that is not legally binding). Through these instruments, it can be concluded that the provisions in UNDRIP exceed the obligations stated in ILO Convention No. 169, for example is UNDRIP establishing obligations for the existence of PADIA in the use of traditional knowledge.

\subsection{International Environmental Law Regime}

Indigenous peoples play an important role in the development of the environment. Indigenous peoples' activities are seen as activities that have the potential to support nature conservation. All indigenous peoples share spiritual, cultural, social and economic relations with their traditional lands. Traditional laws, customs and practices reflect the attachment to land and the responsibility to preserve traditional land for future generations to use.[21] In interacting with their environment, indigenous people develop traditional knowledge as ways to survive. Several times international agreements in the field of environmental law allude to the right of indigenous peoples to traditional knowledge.

One of them is Article $8(\mathrm{~J})$ of the Convention on Biological Diversity (CBD) which requires 3 obligations of the parties of the parties to it. Article 8 (j) places three obligations of the Parties to the CBD. First, state parties must "respect, preserve and maintain knowledge, innovations and practices of indigenous and local communities embodying traditional lifestyles".Part of this provision clearly includes a call to respect indigenous peoples. In addition, States parties must promote '... wider applications with the approval and involvement of the holders of such knowledge, innovations and practices ...' because of their relevance for the conservation and sustainable use of biodiversity. In addition to these reasons, this provision is also often understood to include the interest of indigenous peoples to generate income from marketing their knowledge or products produced.[15]

Second, this provision also emphasizes "approval and involvement of the holders of such knowledge, innovations and practices". As these words clearly indicate by referring to 'approval and involvement' and 'right holder', Article 8 (j) views a kind of ownership position of traditional knowledge holders. The term 'rights' in this context refers to a more general concept of the rights of indigenous and local communities than existing rights under intellectual property rights that apply in a technical sense. Furthermore, agreement and involvement as mentioned in the provision certainly means that indigenous peoples can reject the broader application of their knowledge.[15]

Third, Article 8 (j) of the CBD further outlines these aspects in calling for encouragement to, “... the equitable sharing of benefits arising from the utilization of such knowledge, innovations and practices". It is widely understood that this kind of benefit sharing must be 
based on an agreement concluded before the disclosure of knowledge based on information provided by potential users in their interests, potential uses and commercial perspectives.[21]

Furthermore, the CBD also stipulates that access to traditional knowledge innovations and local community practices must be subject to the Preliminary Information Based Agreement (PADIA) of the traditional knowledge holders. PADIA is an implication of state control mechanisms in access to genetic resources and traditional knowledge contained in Article 15 paragraph 5 of the CBD as 'prior informed consent'.

In addition to PADIA, in Article 1, 15, and 19 the CBD emphasized that bioprospection activities must be subject to fair and equitable access and benefit sharing or access and distribution of benefits that are fair and balanced (ABS). The economic benefits that can be derived from traditional knowledge of indigenous peoples lead to the idea that monetary compensation will function as an incentive to conserve natural resources and to share indigenous people's knowledge with external actors,[22] for example foreigners.

Although the CBD has stipulated Article 8 (j) to protect indigenous peoples over traditional knowledge, the CBD does not have an indication to resolve complex technical questions and distributions derived from vague terms such as for example, what is not 'fair' or 'balanced' 'in terms of profit sharing.[7]

After the CBD, the Nagoya Protocol on Access to Genetic Resources and the Fair and Balanced Profit Sharing Arising from Utilization of the Convention on Biodiversity or the Nagoya Protocol on Access to Genetic Resources and the Fair and Equitable Sharing of Benefits Arising from Their Utilization to the Convention on Biological Diversity 2010 (Nagoya Protocol) The Nagoya Protocol broadens the text of the CBD by detailing obligations in relation to the distribution of benefits and access to genetic resources and traditional knowledge associated with these resources.

The Nagoya Protocol emphasizes the protection of the rights of indigenous peoples to traditional knowledge in Article 5 paragraphs 5 and 7 of the Nagoya Protocol which in essence emphasizes that there must be a sharing of benefits, on the basis of using fair and balanced traditional knowledge, and based on mutual agreement and emphasizes access to traditional knowledge must obtained PADIA beforehand. Specifically for profit sharing, this protocol specifies the implementation of benefit sharing determined by Mutually Agreed Terms (MAT), such as conditions, types, time and procedures or mechanisms for the distribution of profits. [23] Benefits arising from the use of traditional knowledge can be in the form of monetary or non-monetary benefits.

Based on the provisions of the CBD and the Nagoya Protocol, it can be concluded that all parties, including foreign parties, who make use of traditional knowledge held by indigenous peoples must take PADIA steps, establish MAT so that their actions are permitted and not, and finally establish ABS so the benefits derived from the use of traditional knowledge can be recovered for social, economic, cultural and general welfare.

\section{Conclusion}

The legal protection of indigenous peoples' rights to traditional knowledge has been regulated internationally in several international legal regimes, which at least consist of, Human Rights Law (Universal Declaration of Human Rights, International Covenant on Economic, Social and Cultural Rights, and International Covenant on Civil Rights and Politics), Ad Hoc Law on Indigenous Peoples (International Labor Organization Convention 
No. 169 on Indigenous Peoples in Independent Countries and the United Nations Declaration on the Rights of Indigenous Peoples) and International Environmental Law (Convention on Biological Diversity and Protocol Nagoya on Access to Genetic Resources and the Equitable and Balanced Profit Sharing Arising from Their Utilization of the Convention on Biological Diversity). Various instruments of this legal regime require all parties to fulfill, maintain, and respect the rights of indigenous peoples. With regard to traditional knowledge, the use of foreign parties must be based on several things that must be agreed with indigenous peoples such as the Preliminary Information Agreement (PADIA) and the Agreement on Access and Distribution of Benefits.

\section{References}

[1] G. Dutfield, "Identification of Outstanding ABS Issues: Access to GR and IPR, What is biopiracy?, International Expert Workshop on Access to Genetic Resources and Benefit Sharing (2004).”.

[2] R. Tsosie, "Tribal Data Governance and Informational Privacy: Constructing Indigenous Data Sovereignty," Mont. L. Rev., vol. 80, p. 229, 2019.

[3] F. Mauro and P. D. Hardison, "Traditional knowledge of indigenous and local communities: international debate and policy initiatives," Ecol. Appl., vol. 10, no. 5, pp. 1263-1269, 2000.

[4] J. Gosart, "The Protection of the Traditional Knowledge of Indigenous Peoples," University of California, 2013.

[5] Mandala Projects, "TED CASE STUDIES - Basmati. Geographic Indications and International Trade (GIANT)." [Online]. Available: http://mandalaprojects.com/giantproject/basmati.htm. [Accessed: 03-Jul-2020].

[6] B. A. K. N. Djundjunan, "Sistem Hukum Internasional Belum Memberikan Perlindungan Efektif terhadap GRTKTCE," Tabloid Diplomasi Komunikasi dan Interaksi, 2012.

[7] J. Tustin, "Traditional knowledge and intellectual property in Brazilian biodiversity law," Tex. Intell. Prop. LJ, vol. 14, p. 131, 2005.

[8] M. R. Ayu, H. Alexander, and W. Puspitasari, Hukum sumber daya genetik, pengetahuan tradisional, dan ekspresi budaya tradisional di Indonesia. Bandung: Alumni, 2014.

[9] G. Dutfield, Protecting traditional knowledge: pathways to the future, no. 16. International Centre for Trade and Sustainable Development (ICTSD), 2006.

[11] B. H. Bangun, "The Existences of International Law in the Establishment of Indonesian National Regulation on the Protection of Traditional Knowledge," J. Huk. Nov., vol. 10, no. 1, p. 10, 2019.

[12] J. Erstling, "Using patent to protect traditional knowledge," Tex. Wesley. L. Rev., vol. 15 , p. $295,2008$.

[13] F. Lenzerini, Traditional Knowledge, Biogenetic Resources, Genetic Engineering and 
Intellectual Property Right, Genetic Engineering and the World Trade System, World Trade Forum Series. Cambridge: Cambridge University Press, 2008.

[14] P. I. Jaszi, "Traditional Culture: A Step Forward for Protection in Indonesia-A Research Report," Jakarta, Indones. Inst. Press Dev. Stud., 2009.

[15] S. Von Lewinski, Indigenous heritage and intellectual property: genetic resources, traditional knowledge and folklore. Kluwer Law International BV, 2008.

[16] D. B. Suagee, "Self-determination for Indigenous Peoples at the Dawn of the Solar Age," U. Mich. JL Reform, vol. 25, p. 671, 1991.

[17] UN Human Rights Committee (HRC), "CCPR General Comment No. 23: Article 27 (Rights of Minorities), 8 April 1994, CCPR/C/21/Rev.1/Add.5.” [Online]. Available: https://www.refworld.org/docid/453883fc0.html. [Accessed: 06-May-2020].

[18] R. Stavenhagen, Peasants, culture and Indigenous peoples: Critical issues, vol. 4. Springer Science \& Business Media, 2012.

[19] J. Hohmann and M. Weller, The UN declaration on the rights of indigenous peoples: A commentary. Oxford University Press, 2018.

[20] A. Aust, Modern treaty law and practice. Cambridge University Press, 2013.

[21] Office of the United Nations High Commissioner for Human Rights, "Leaflet No. 10: Indigenous Peoples and the Environment." [Online]. Available: https://www.ohchr.org/Documents/Publications/GuideIPleaflet10en.pdf. [Accessed: 08-May-2020].

[22] T. R. Eimer and V. Schüren, "Global Wordings and Local Meanings: Traditional Knowledge Regulation in India and Brazil," 2013.

[23] T. Greiber, An explanatory guide to the Nagoya Protocol on access and benefitsharing, no. 83. IUCN, 2012. 